\title{
Teaching NeuroImages: Collet-Sicard syndrome and hearing loss with glomus jugulotympanicum
}

Aravind Ganesh, MD, DPhil, Zarina Assis, MD, Daniel Fok, MD, FRCPC, J. Gregory Cairncross, MD, Simerpreet S. Bal, MD, FRCPC, and Sarah Furtado, MD, PhD, FRCPC

Neurology ${ }^{\circledR}$ 2019;93:e1408-e1409. doi:10.1212/WNL.0000000000008205

\section{Correspondence}

Dr. Ganesh

aravindganeshy@yahoo.ca

Figure $1 \mathrm{CT}$ head/neck
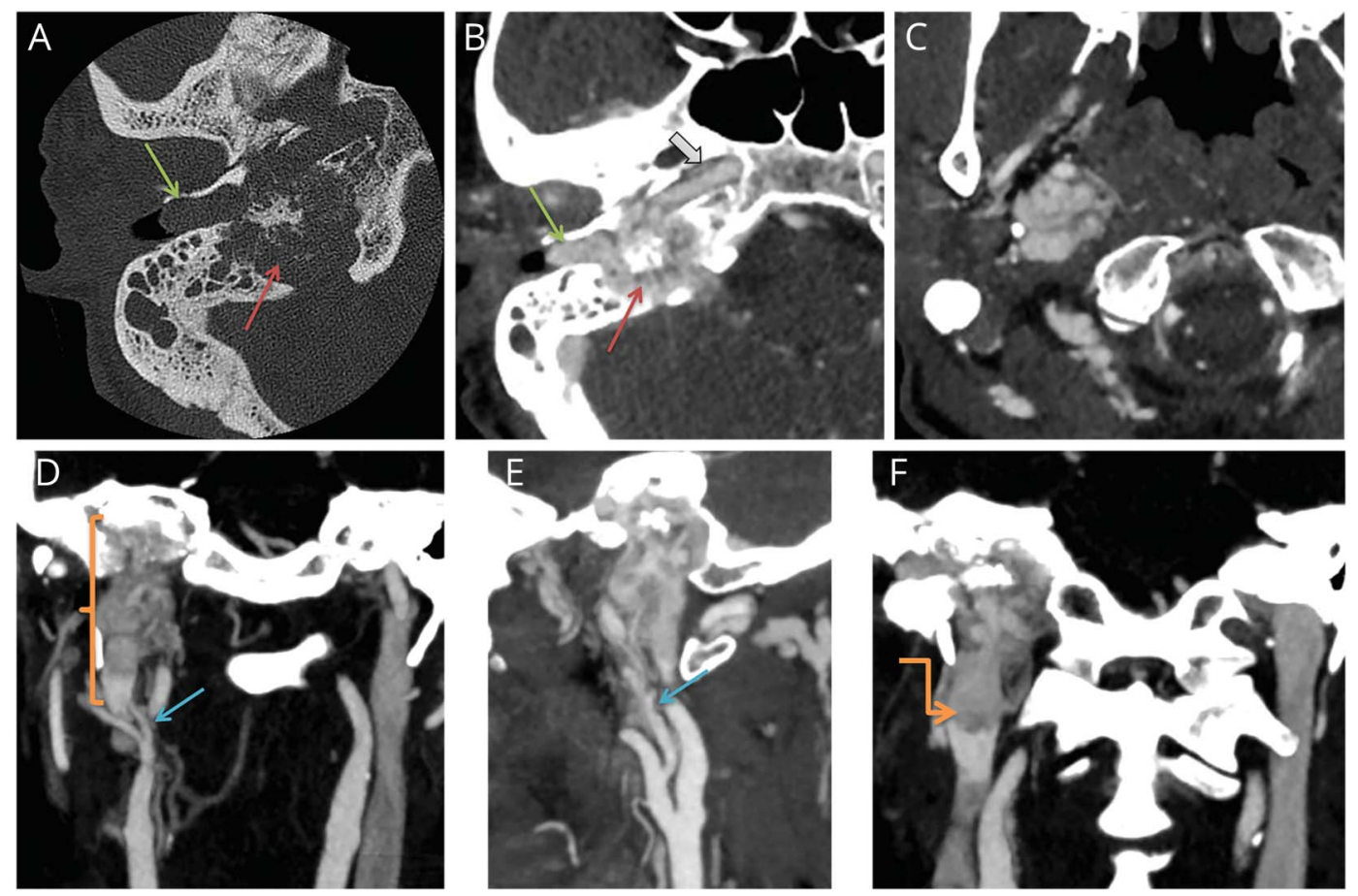

Axial temporal bone study (A) shows expansile lytic right jugular fossa lesion (red arrow) extending into external ear canal (green arrow), contrast-enhancing (B), extending within carotid sheath, displacing internal carotid artery anteriorly (C). Contrast-enhanced CT neck (D, coronal) demonstrates craniocaudal extension along carotid space (orange bracket), hypertrophied external carotid feeding branches (blue arrow, E: sagittal), and internal jugular vein invasion (orange arrow, F: coronal).

A 56-year-old woman presented with headache, vomiting for 3 days, and right hearing loss, tinnitus, and dysphagia over 3 months. Examination showed decreased right palate elevation and atrophy of right sternocleidomastoid, trapezius, and tongue with rightward tongue deviation, indicating ColletSicard syndrome (involving cranial nerves IX-XII in jugular foramen and hypoglossal canal). ${ }^{1}$ Hearing loss suggested auditory canal extension. Imaging showed a right skull base mass in keeping with glomus tumor (figures 1 and 2). Given surgical risks, radical radiotherapy was performed, arresting tumor growth. Glomus jugulare tumors, hypervascular paragangliomas, are the most common tumors in the jugular foramen and can extend into the middle ear (jugulotympanicum). ${ }^{2}$

\section{MORE ONLINE}

$\rightarrow$ Teaching slides

links.lww.com/WNL/

A964

\section{Author contributions}

A. Ganesh: concept, acquisition of data, and writing the initial drafts of the manuscript. Z. Assis: acquisition of data and critical revision of manuscript for intellectual content. D. Fok: acquisition of data and critical revision of manuscript for intellectual content. J.G. Cairncross: concept and critical revision of manuscript for intellectual content. S.B. Bal: concept and critical revision of manuscript 

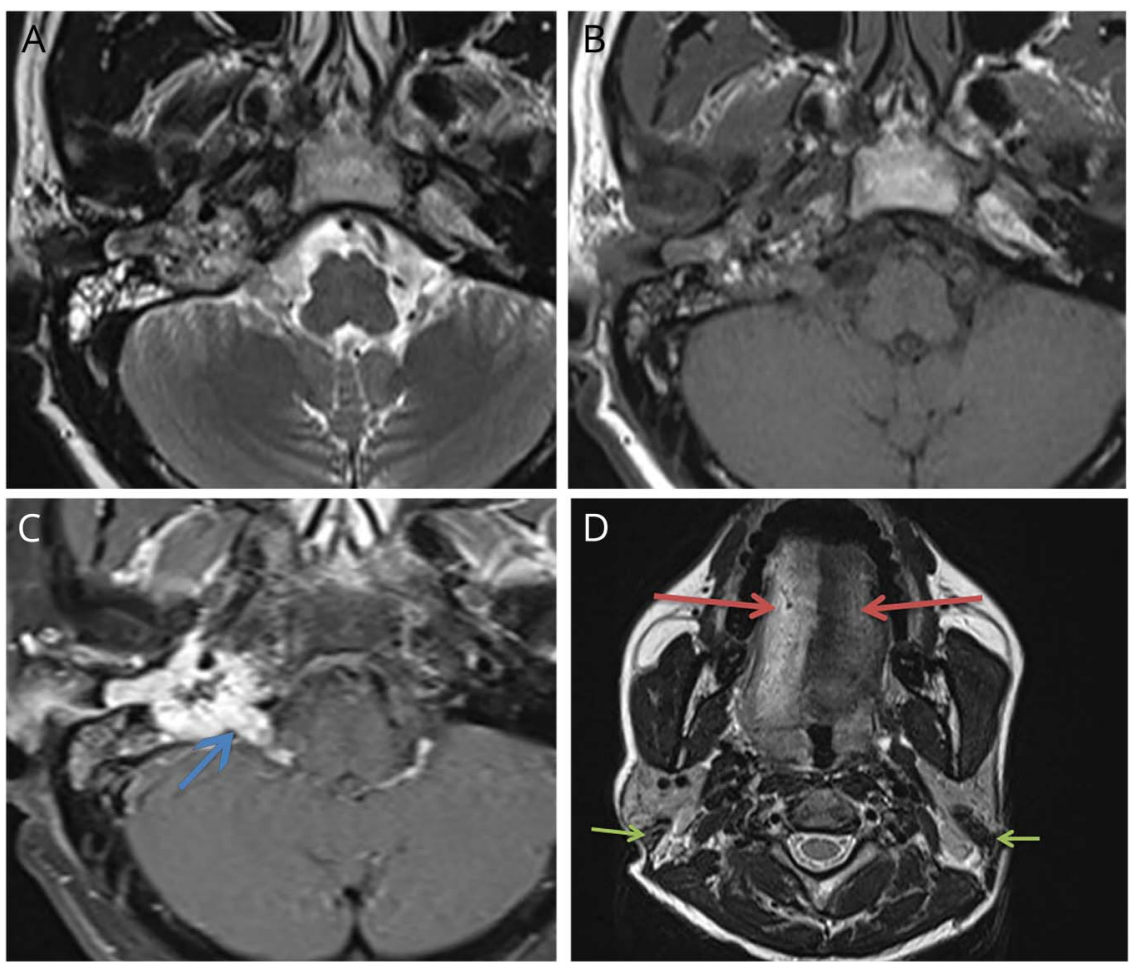

Axial T2-weighted (A) and T1-weighted (B) MR show right jugular fossa lesion with salt-andpepper appearance. Postcontrast T1-weighted MRI (C) shows enhancement and extension into cerebello-medullary angle through widened hypoglossal canal (blue arrow). Axial T2-weighted MRI (D) shows fatty degeneration of right tongue (red arrows) and atrophy of right sternocleidomastoid (green arrows).

for intellectual content. S. Furtado: concept and critical revision of manuscript for intellectual content.

\section{Study funding}

No targeted funding reported.

\section{Disclosure}

A. Ganesh serves on the Neurology ${ }^{\circledR}$ editorial board. Z. Assis, D. Fok, J. Cairncross, S. Bal, and S. Furtado report no disclosures relevant to the manuscript. Go to Neurology.org/ $\mathrm{N}$ for full disclosures.

\section{References}

1. Schuster NM, Karnezis S, Restrepo L. Teaching NeuroImages: granulomatosis with polyangiitis causing Collet-Sicard syndrome and refractory headache. Neurology 2015;85:e179-e180.

2. Fayad JN, Schwartz MS, Brackmann DE. Treatment of recurrent and residual glomus jugulare tumors. Skull Base 2009;19:92-98. 


\section{Neurology}

\section{Teaching NeuroImages: Collet-Sicard syndrome and hearing loss with glomus jugulotympanicum}

Aravind Ganesh, Zarina Assis, Daniel Fok, et al.

Neurology 2019;93;e1408-e1409

DOI 10.1212/WNL.0000000000008205

This information is current as of September 30, 2019

Updated Information \& Services

References

Subspecialty Collections

Permissions \& Licensing

Reprints including high resolution figures, can be found at: http://n.neurology.org/content/93/14/e1408.full

This article cites 2 articles, 1 of which you can access for free at: http://n.neurology.org/content/93/14/e1408.full\#ref-list-1

This article, along with others on similar topics, appears in the following collection(s):

All Clinical Neurology

http://n.neurology.org/cgi/collection/all_clinical_neurology All Oncology

http://n.neurology.org/cgi/collection/all_oncology

CT

http://n.neurology.org/cgi/collection/ct

MRI

http://n.neurology.org/cgi/collection/mri

Information about reproducing this article in parts (figures,tables) or in its entirety can be found online at:

http://www.neurology.org/about/about_the_journal\#permissions

Information about ordering reprints can be found online:

http://n.neurology.org/subscribers/advertise

Neurology ${ }^{\circledR}$ is the official journal of the American Academy of Neurology. Published continuously since 1951, it is now a weekly with 48 issues per year. Copyright (C 2019 American Academy of Neurology. All rights reserved. Print ISSN: 0028-3878. Online ISSN: 1526-632X.

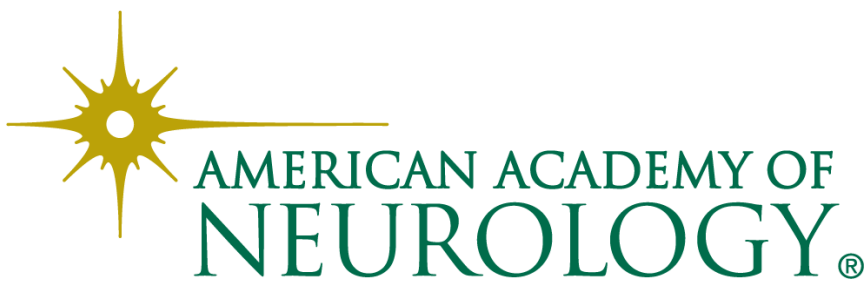

